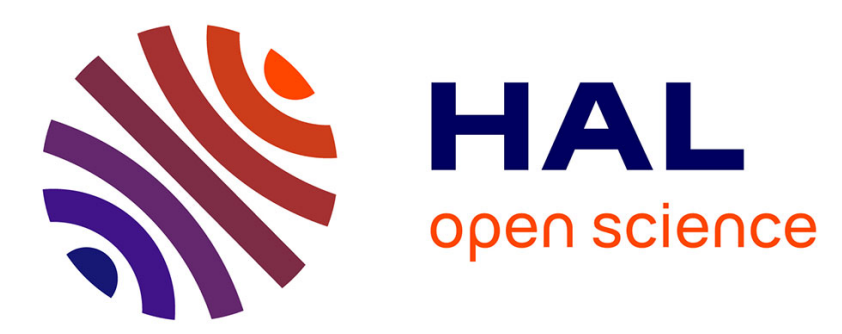

\title{
Chemical decoration in cubic approximant and quasicrystal in the Al-Cu-Fe system
}

Virginie Simonet, Francoise Hippert, Richard Brand, Yvonne Calvayrac, Juan Rodriguez-Carvajal, Anne Sadoc

\section{- To cite this version:}

Virginie Simonet, Francoise Hippert, Richard Brand, Yvonne Calvayrac, Juan Rodriguez-Carvajal, et al. Chemical decoration in cubic approximant and quasicrystal in the Al-Cu-Fe system. Philosophical Magazine, 2005, 86 (03-05), pp.573-579. 10.1080/14786430500278940 . hal-00513596

\author{
HAL Id: hal-00513596 \\ https://hal.science/hal-00513596
}

Submitted on 1 Sep 2010

HAL is a multi-disciplinary open access archive for the deposit and dissemination of scientific research documents, whether they are published or not. The documents may come from teaching and research institutions in France or abroad, or from public or private research centers.
L'archive ouverte pluridisciplinaire HAL, est destinée au dépôt et à la diffusion de documents scientifiques de niveau recherche, publiés ou non, émanant des établissements d'enseignement et de recherche français ou étrangers, des laboratoires publics ou privés. 


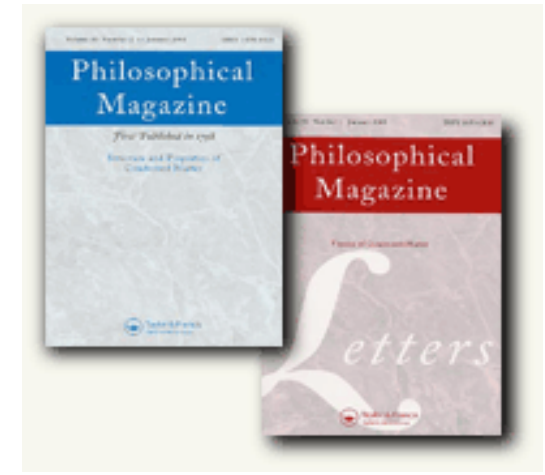

\section{Chemical decoration in cubic approximant and quasicrystal in the Al-Cu-Fe system}

\begin{tabular}{|r|l|}
\hline Journal: & Philosophical Magazine \& Philosophical Magazine Letters \\
\hline Manuscript ID: & TPHM-05-May-0170.R1 \\
\hline Journal Selection: & Philosophical Magazine \\
\hline Author: & 19-Jul-2005 \\
\hline Complete List of Authors: & $\begin{array}{l}\text { Simonet, Virginie; Laboratoire L. Néel, CNRS } \\
\text { HIPPERT, Francoise; Laboratoire des Materiaux et du Genie } \\
\text { Physique, ENSPG } \\
\text { BRAND, Richard; Universität Duisburg-Essen, Department of } \\
\text { Physics } \\
\text { CALVAYRAC, Yvonne; CECM, CNRS } \\
\text { RODRIGUEZ-CARVAJAL, Juan; Laboratoire Léon Brillouin, CEA - } \\
\text { CNRS } \\
\text { Sadoc, Anne; Université de Cergy Pontoise, LPMS }\end{array}$ \\
\hline Keywords (user supplied): & local order \\
\hline Keywords: & X-ray diffraction, structure analysis, quasicrystals, EXAFS \\
\hline
\end{tabular}

\section{(5) ScholarONE \\ Manuscript Central}




\title{
Chemical decoration in cubic approximant and quasicrystal in the Al-Cu-Fe system
}

\author{
V.SIMONET ${ }^{1}$, F. HIPPERT ${ }^{2 *}$, R.A. BRAND ${ }^{3}$, Y. CALVAYRAC $^{4}$, \\ J. RODRIGUEZ-CARVAJAL ${ }^{5}$ and A. SADOC ${ }^{6}$ \\ ${ }^{1}$ Laboratoire Louis Néel, CNRS, BP 166, F-38042 Grenoble Cedex 9, France \\ ${ }^{2}$ LMGP, ENSPG, BP 46, F-38402 Saint Martin d'Hères Cedex, France \\ ${ }^{3}$ Department of Physics, Universität Duisburg-Essen, D-47048 Duisburg, Germany \\ ${ }^{4}$ CECM/CNRS, 15 rue G. Urbain, F-94407 Vitry-sur-Seine Cedex, France \\ ${ }^{5}$ Laboratoire Léon Brillouin (CEA-CNRS), CEA/Saclay, F-91191 Gif sur Yvette Cedex, \\ France \\ ${ }^{6}$ LPMS, Université de Cergy-Pontoise, F-95031 Neuville sur Oise Cedex, France
}

\begin{abstract}
The local order in the Al-Cu-Fe quasicrystal and in two of its approximants has been investigated by extended X-ray absorption fine structure (EXAFS) studies at the $\mathrm{Cu}$ and $\mathrm{Fe}$ K-edges. The chemical occupation of the crystallographic sites in the $1 / 1$ cubic $\alpha-\mathrm{Al}_{55} \mathrm{Si}_{7} \mathrm{Cu}_{25.5} \mathrm{Fe}_{12.5}$ phase is revisited. From these results, a model for the chemical short-range order in the $\mathrm{Al}_{62} \mathrm{Cu}_{25.5} \mathrm{Fe}_{12.5}$ quasicrystal is proposed.
\end{abstract}

Keywords: quasicrystals, EXAFS,X-ray diffraction, structure analysis, local order 


\section{Introduction}

An accurate description of the atomic positions in quasicrystals (QC) is available $[1,2]$ but their occupation by the different chemical species is still not completely solved. This is an important question because the chemical local order, especially the Al-transition metal bonds, plays a central role in determining the atypical electronic properties of QCs and probably their stability through the pseudo-gap formation. A way to obtain information on the local order in QCs is provided by the existence of approximants. With increasing integers $\mathrm{p}$ and $\mathrm{q}$ which characterize the approximant order, the size of the unit cell increases and the local structure approaches that of the parent QC on an increasing scale. In the Al-Cu-Fe system, several high order approximants $(\mathrm{p} / \mathrm{q}=3 / 2,4 / 3 \ldots)$ exist for compositions similar to those of the quasicrystal (around $\mathrm{Al}_{62} \mathrm{Cu}_{25.5} \mathrm{Fe}_{12.5}$ ) [3]. Besides, a cubic 1/1 phase, hereafter denoted as $\alpha$, can be stabilized by the substitution of a few percent of Si for Al, in a small domain around $\mathrm{Al}_{55} \mathrm{Si}_{7} \mathrm{Cu}_{25.5} \mathrm{Fe}_{12.5}[4,5]$. The $\mathrm{Al}(\mathrm{Si})-\mathrm{Cu}-\mathrm{Fe}$ system offers therefore the opportunity to study experimentally the evolution of the local order from the relatively simple cubic $1 / 1$ phase to complex approximants and finally to the quasicrystal. For this purpose EXAFS studies have been performed at the $\mathrm{Cu}$ and $\mathrm{Fe} \mathrm{K}$-edges in the cubic $\alpha-\mathrm{Al}_{55} \mathrm{Si}_{7} \mathrm{Cu}_{25.5} \mathrm{Fe}_{12.5}$ and in the QC- $\mathrm{Al}_{62} \mathrm{Cu}_{25.5} \mathrm{Fe}_{12.5}$ and at the $\mathrm{Cu}$ K-edge in rhombohedral and QC phases with exactly the same composition $\mathrm{Al}_{62.8} \mathrm{Cu}_{26} \mathrm{Fe}_{11.2}$.

The structure of the rhombohedral phase is still unknown. For the $\alpha-\mathrm{Al}_{55} \mathrm{Si}_{7} \mathrm{Cu}_{25.5} \mathrm{Fe}_{12.5}$ phase, two slightly different structural models have been proposed from X-ray diffraction [6, 7]. The occupied crystallographic positions are almost identical but the chemical occupation differs significantly. Besides, none of these models was found able to explain the present EXAFS data. This led us to revisit the structure of the $\alpha-\mathrm{Al}_{55} \mathrm{Si}_{7} \mathrm{Cu}_{25.5} \mathrm{Fe}_{12.5}$ phase by combining X-ray and neutron powder diffraction and EXAFS analysis [5]. The obtained 


\section{Experiments}

Ribbons made by planar flow casting were annealed under high vacuum: 24 hours at $650^{\circ} \mathrm{C}$ for $\alpha-\mathrm{Al}_{55} \mathrm{Si}_{7} \mathrm{Cu}_{25.5} \mathrm{Fe}_{12.5}, 72$ hours at $705{ }^{\circ} \mathrm{C}$ for $\mathrm{Al}_{62.8} \mathrm{Cu}_{26} \mathrm{Fe}_{11.2}$ in its rhombohedral state and 2 hours at $740^{\circ} \mathrm{C}$ in its $\mathrm{QC}$ state, and 2 hours at $800^{\circ} \mathrm{C}$ for the $\mathrm{QC}-\mathrm{Al}_{62} \mathrm{Cu}_{25.5} \mathrm{Fe}_{12.5}$. Compositions are the nominal ones. No foreign phase was detected within the accuracy of X-ray powder diffraction. Ribbons were ground into a fine powder for the EXAFS experiments which were performed on the D42 beamline of the DCI storage ring at LURE (Orsay, France) in the transmission mode at the Fe K-edge $(7112 \mathrm{eV})$ and at the $\mathrm{Cu}$ K-edge $(8979 \mathrm{eV})$ at $15 \mathrm{~K}$. The extraction and analysis of the EXAFS oscillations were performed using the FEFF package $[5,9]$. The Fourier transform (FT) of the $\mathrm{k}^{2} \chi(\mathrm{k})$ signal was calculated in the k-range [3.4 - $12 \AA^{-1}$ ] by using a Hanning window. Fits were performed in restricted r-ranges $([1.7-3 \AA]$ at the Fe K-edge and [1.3 - 3.1 $\mathrm{A}]$ at the Cu K-edge).

\section{Results}

The modulus and imaginary part of the FT of the measured EXAFS oscillations $\mathrm{k}^{2} \chi(\mathrm{k})$ are reported in Figures 1 and 2. At the $\mathrm{Cu}$ K-edge, a very small composition effect is detected when comparing the two QCs but the FT of the rhombohedral approximant and the QC of same composition, $\mathrm{Al}_{62.8} \mathrm{Cu}_{26} \mathrm{Fe}_{11.2}$, are identical up to $6 \AA$, which reveals identical local 
environments around $\mathrm{Cu}$ in this range (Fig. 1). Although the FTs of the $\mathrm{QC}-\mathrm{Al}_{62} \mathrm{Cu}_{25.5} \mathrm{Fe}_{12.5}$ and $\alpha-\mathrm{Al}_{55} \mathrm{Si}_{7} \mathrm{Cu}_{25.5} \mathrm{Fe}_{12.5}$ phases are quite similar, significant evolutions are observed especially around $\mathrm{Cu}$ and to a lesser extent around Fe (Fig.2).

\subsection{Local order in the cubic approximant $\alpha-\mathrm{Al}_{55} \mathrm{Si}_{7} \mathrm{Cu}_{25.5} \mathrm{Fe}_{12.5}$}

$\mathrm{Fe}$ and $\mathrm{Cu}$ spectra were fitted simultaneously. All possible single scattering paths in the fitted r-range around a given absorbing atom were considered (more than 50 at the $\mathrm{Cu} \mathrm{K}$-edge). No distinction was made between $\mathrm{Al}$ and $\mathrm{Si}$. The structural model obtained from the analysis of X-ray and neutron powder diffraction data (Table 1) has been used as a starting point. The distances between the absorbing atom and its neighbours were allowed to vary but the same relative variation $\delta \mathrm{r} / \mathrm{r}$ was imposed for all similar pairs, i.e. involving the same kind of atoms, in order to limit the number of parameters. The relative mean displacement $\sigma^{2}$ of a pair (Debye-Waller factor) was refined but held equal for all similar pairs. In order to further improve the fit, the chemical nature of atoms on sites (3), (4), (5), (6), (10) occupied by a mixture of different species, was allowed to vary, the stoichiometry being held fixed. Only small changes from the initial model are necessary to converge to the very good fits shown in Figure 2. In particular, the coexistence of $\mathrm{Al}, \mathrm{Cu}$ and $\mathrm{Fe}$ on site (5) is confirmed by the EXAFS analysis. It is interesting to describe the results by analysing the average environment of $\mathrm{Cu}$ or $\mathrm{Fe}$ (Table 2). One of the most striking results is that $\mathrm{Fe}$ has no Fe first neighbours and is surrounded mainly by $\mathrm{Al}$ atoms and a small proportion of $\mathrm{Cu}$. The calculated summed contributions of all neighbours of the same kind around a given absorbing atom are drawn in Figure 2, which demonstrates that the double peak in the FT at the $\mathrm{Cu}$ K-edge originates from destructive interference between the $\mathrm{Al}$ and $\mathrm{Cu}$ contributions. 


\subsection{Local order in the quasicrystal QC- $\mathrm{Al}_{62} \mathrm{Cu}_{25.5} \mathrm{Fe}_{12.5}$}

A fit of the EXAFS spectra of the QC was attempted, starting from the results of the EXAFS analysis in the $\alpha$-phase and using the same fit procedure. In addition, the possibility of adding a Fe atom at the $(1 / 2,1 / 2,1 / 2)$ position was tested. Results are presented in Tables 1 and 2 and in Figure 2. All pair distances in the QC are slightly smaller than in the $\alpha$-phase and the average number of neighbours changes slightly (Table 2). As a main result, in the QC, the $\mathrm{Cu}$ atoms in site (5) are totally replaced by $\mathrm{Al}$ and occupy site (6) instead. The fits are slightly better with both centres of the Mackay clusters filled with one Fe atom. These results show that the local order in the QC up to $3 \AA$ can be accounted for by introducing only small variations in the model of the $\alpha$-phase. This confirms the structural and chemical closeness of both phases. However, the details of the proposed structure and its description in terms of icosahedral clusters must be confirmed by other methods since EXAFS alone cannot solve complex structures.

\section{Conclusion}

From a complex EXAFS analysis, associated to joined X-ray and neutron diffraction, we have been able to determine the chemical decoration in the cubic $1 / 1 \quad \alpha-\mathrm{Al}_{55} \mathrm{Si}_{7} \mathrm{Cu}_{25.5} \mathrm{Fe}_{12.5}$ approximant. Fe atoms are found in the outer icosahedra of the two MacKay clusters (sites (5) and (9)). This is similar to the case of $\mathrm{Ru}$ in the $1 / 1 \mathrm{Al}(\mathrm{Si})-\mathrm{Cu}-\mathrm{Ru}[10]$ or $\mathrm{Mn}$ in the $1 / 1$ $\mathrm{Al}(\mathrm{Si})-\mathrm{Mn}$ approximants [8]. The existence of a composition domain for the cubic $\alpha-\mathrm{Al}(\mathrm{Si})-\mathrm{Cu}-\mathrm{Fe}$ results mainly from the variations of the $\mathrm{Fe}, \mathrm{Al}$ and $\mathrm{Cu}$ occupations on site (5) keeping site (9) entirely filled by Fe [5]. The results on the cubic $\alpha$-phase have then been used 
to propose a chemical decoration in the quasicrystal, pointing out the similarity in the local order in the two phases on a scale at least up to $3 \AA$. An important conclusion of the present work is that an analysis of all scattering paths is mandatory to interpret the EXAFS oscillations in complex phases. Grouping neighbours into shells with a Gaussian distribution of distances, as done in previous EXAFS analysis of approximants and quasicrystals, leads to erroneous results, in particular to artificially low coordination numbers, because it does not take into account destructive interferences between individual scattering paths and because the assumption of a Gaussian distribution is not valid. 


\section{References}

[1] D. Gratias, F. Puyraimond, M. Quiquandon and A. Katz, Phys. Rev. B 6324202 (2000).

[2] A.Yamamoto, H. Takakura and A. P. Tsai, Phys. Rev. B 68094201 (2003).

[3] M. Quiquandon, A. Quivy, J. Devaud et al , J. of Physics: Condens. Matter 82487 (1996)

[4] A. Quivy, M. Quiquandon, Y. Calvayrac et al, J. of Physics: Condens. Matter 84223 (1996).

[5] V. Simonet, F. Hippert, R.A. Brand et al, accepted for publication in Phys. Rev. B

[6] Z.-M. Stadnik, T. Takeuchi, N. Tanaka and U. Mizutani, J. of Physics: Condens. Matter 15 6365 (2003).

[7] F. Puyraimond, M. Quiquandon, D. Gratias et al, Acta Cryst. A 58391 (2002).

[8] K. Sugiyama, N. Kaji and K. Hiraga, Acta Cryst. C 54445 (1998).

[9] J. J. Rehr and A. L. Ankudinov, J. Synchrotron Rad. 861 (2001) and refs therein.

[10] T. Takeuchi and U. Mizutani, J. of Alloys and Compounds 342416 (2002). 


\begin{tabular}{|c|c|c|c|c|c|c|c|c|c|c|c|c|c|}
\hline \multicolumn{9}{|c|}{ Cluster at $(0,0,0)$} & \multicolumn{5}{|c|}{ Cluster at $(1 / 2,1 / 2,1 / 2)$} \\
\hline shell & centre & ico & & & ico & rhor & jico & ico & centre & ico & & & ico \\
\hline Site & $\begin{array}{l}\text { (1) } \\
\text { 1a }\end{array}$ & $\begin{array}{l}\text { (2) } \\
12 \mathrm{j}\end{array}$ & $\begin{array}{l}\text { (3) } \\
241\end{array}$ & $\begin{array}{l}\text { (4) } \\
6 \mathrm{e}\end{array}$ & $\begin{array}{l}(5) \\
12 \mathrm{j}\end{array}$ & $\begin{array}{l}(11) \\
12 \mathrm{j}\end{array}$ & $\begin{array}{l}(12) \\
12 \mathrm{k}\end{array}$ & $\begin{array}{l}\text { (10) } \\
\text { 6f }\end{array}$ & $1 b$ & $\begin{array}{l}6) \\
12 \mathrm{k}\end{array}$ & $\begin{array}{l}\text { (7) } \\
241\end{array}$ & $\begin{array}{l}\text { (8) } \\
6 \mathrm{~h}\end{array}$ & $\begin{array}{l}(9) \\
12 \mathrm{k}\end{array}$ \\
\hline $\begin{array}{c}\alpha \\
\text { diffrac. }\end{array}$ & $\begin{array}{c}\mathrm{Fe} \\
1\end{array}$ & $\begin{array}{c}2.414 \\
\mathrm{Al} \\
10.1\end{array}$ & \begin{tabular}{|c|}
4.537 \\
$\mathrm{Cu} / \mathrm{Al}$ \\
$16.8 / 7.2$
\end{tabular} & $\begin{array}{l}4.627 \\
\mathrm{Cu} / \mathrm{Al} \\
3.8 / 2.2\end{array}$ & $\begin{array}{c}4.690 \\
\mathrm{Cu} / \mathrm{Al} / \mathrm{Fe} \\
5.6 / 2.4 / 4\end{array}$ & $\begin{array}{c}6.349 \\
\mathrm{Al} \\
12\end{array}$ & $\begin{array}{c}6.505 \\
\mathrm{Al} \\
12\end{array}$ & $\begin{array}{l}7.276 \\
\mathrm{Cu} / \mathrm{Al} \\
5.6 / 0.4\end{array}$ & empty & $\begin{array}{c}2.415 \\
\mathrm{Al} / \mathrm{Cu} \\
9.2 / 2.8\end{array}$ & $\begin{array}{c}4.670 \\
\mathrm{Al} \\
24\end{array}$ & $\begin{array}{c}4.732 \\
\mathrm{Al} \\
6\end{array}$ & $\begin{array}{c}4.653 \\
\mathrm{Fe} \\
12\end{array}$ \\
\hline $\begin{array}{c}\alpha \\
\text { EXAFS }\end{array}$ & $\begin{array}{c}\mathrm{Fe} \\
1\end{array}$ & $\begin{array}{c}\mathrm{Al} \\
10.1\end{array}$ & $\begin{array}{c}\mathrm{Cu} / \mathrm{Al} \\
15.2 / 8.8\end{array}$ & $\begin{array}{c}\mathrm{Cu} / \mathrm{Al} \\
6\end{array}$ & $\begin{array}{l}\mathrm{Cu} / \mathrm{Al} / \mathrm{Fe} \\
5.2 / 2.8 / 4\end{array}$ & $\begin{array}{l}\mathrm{Al} \\
12\end{array}$ & $\begin{array}{l}\mathrm{Al} \\
12\end{array}$ & $\begin{array}{c}\mathrm{Cu} \\
6\end{array}$ & empty & $\begin{array}{c}\mathrm{Al} / \mathrm{Cu} \\
9.8 / 2.1\end{array}$ & $\begin{array}{l}\mathrm{Al} \\
24\end{array}$ & $\begin{array}{c}\mathrm{Al} \\
6\end{array}$ & $\begin{array}{l}\mathrm{Fe} \\
12\end{array}$ \\
\hline $\begin{array}{c}\mathrm{QC} \\
\text { EXAFS }\end{array}$ & $\begin{array}{c}\mathrm{Fe} \\
1\end{array}$ & $\begin{array}{c}\mathrm{Al} \\
10.1\end{array}$ & \begin{tabular}{|c|}
$\mathrm{Cu} / \mathrm{Al}$ \\
$15.4 / 8.6$
\end{tabular} & $\begin{array}{c}\mathrm{Cu} \\
6\end{array}$ & $\begin{array}{c}\mathrm{Al} / \mathrm{Fe} \\
9 / 3\end{array}$ & $\begin{array}{l}\mathrm{Al} \\
12\end{array}$ & $\begin{array}{l}\mathrm{A} 1 \\
12\end{array}$ & $\begin{array}{c}\mathrm{Cu} \\
6\end{array}$ & $\begin{array}{c}\mathrm{Fe} \\
1\end{array}$ & $\begin{array}{c}\mathrm{Al} / \mathrm{Cu} \\
3.8 / 8.2\end{array}$ & $\begin{array}{l}\mathrm{Al} \\
24\end{array}$ & $\begin{array}{c}\text { Al } \\
6\end{array}$ & $\begin{array}{l}\mathrm{Fe} \\
12\end{array}$ \\
\hline
\end{tabular}

Table 1: Chemical decoration of the icosahedral clusters in the $\alpha-\mathrm{Al}_{55} \mathrm{Si}_{7} \mathrm{Cu}_{25.5} \mathrm{Fe}_{12.5}$ and $\mathrm{QC}-\mathrm{Al}_{62} \mathrm{Cu}_{25.5} \mathrm{Fe}_{12.5}$ phases. Shell labels "ico", "icosi" and "rhombico" stand for icosahedron, icosidodecahedron and rhombicosidodecahedron respectively. For the $\alpha$-phase, results from X-ray and neutron powder diffraction [5] are reported. The nature and number of the atoms on each crystallographic site (numbered as in Refs. [5, 7]) and their distance from the cluster centre are given. The chemical decoration deduced from the EXAFS analysis is reported for the $\alpha$ and QC phases. 


\begin{tabular}{|l|l|l|l|}
\hline $\begin{array}{l}\text { Sample } \\
\text { edge }\end{array}$ & Al neighbours & Cu neighbours & Fe neighbours \\
\hline$\alpha$ & $\mathrm{N}=9.1$ & $\mathrm{~N}=2.1$ & none \\
Fe K-edge & $\delta \mathrm{r} / \mathrm{r}=0.0116$ & $\delta \mathrm{r} / \mathrm{r}=-0.0066$ & \\
$\mathrm{RF}=0.0094$ & $\sigma^{2}=0.0039 \AA^{2}$ & $\sigma^{2}=0.0039 \AA^{2}$ & \\
\hline$\alpha$ & $\mathrm{N}=7.6$ & $\mathrm{~N}=3.3$ & $\mathrm{~N}=1.0$ \\
Cu K-edge & $\delta \mathrm{r} / \mathrm{r}=-0.0082$ & $\delta \mathrm{r} / \mathrm{r}=+0.0042$ & $\delta \mathrm{r} / \mathrm{r}=-0.0066$ \\
$\mathrm{RF}=0.0021$ & $\sigma^{2}=0.0048 \AA^{2}$ & $\sigma^{2}=0.0048 \AA^{2}$ & $\sigma^{2}=0.0039 \AA^{2}$ \\
\hline
\end{tabular}

\begin{tabular}{|l|l|l|l|}
\hline $\begin{array}{l}\text { Sample } \\
\text { edge }\end{array}$ & Al neighbours & Cu neighbours & Fe neighbours \\
\hline QC & $\mathrm{N}=8.5$ & $\mathrm{~N}=2.7$ & none \\
Fe K-edge & $\delta \mathrm{r} / \mathrm{r}=-0.0035$ & $\delta \mathrm{r} / \mathrm{r}=-0.0157$ & \\
RF=0.0023 & $\sigma^{2}=0.0039 \AA^{2}$ & $\sigma^{2}=0.0065 \AA^{2}$ & \\
\hline QC & $\mathrm{N}=8.1$ & $\mathrm{~N}=2.6$ & $\mathrm{~N}=1.3$ \\
Cu K-edge & $\delta \mathrm{r} / \mathrm{r}=-0.0230$ & $\delta \mathrm{r} / \mathrm{r}=-0.0064$ & $\delta \mathrm{r} / \mathrm{r}=-0.0157$ \\
RF=0.0024 & $\sigma^{2}=0.0034$ & $\sigma^{2}=0.0053$ & $\sigma^{2}=0.0065$ \\
\hline
\end{tabular}

Table 2: Average environment of $\mathrm{Cu}$ and $\mathrm{Fe}$ atoms deduced from EXAFS analysis in the $\alpha-\mathrm{Al}_{55} \mathrm{Si}_{7} \mathrm{Cu}_{25.5} \mathrm{Fe}_{12.5}$ and $\mathrm{QC}-\mathrm{Al}_{62} \mathrm{Cu}_{25.5} \mathrm{Fe}_{12.5}$ phases. $\mathrm{N}$ is the average number of neighbours of a given kind around $\mathrm{Fe}$ or $\mathrm{Cu}$. $\delta \mathrm{r} / \mathrm{r}$ is the relative variation of the distances with respect to those calculated from the crystallographic data of Ref. [5] for the $\alpha$ phase. $\sigma^{2}$ is the relative mean displacement for a pair. RF is the goodness of the fit. 


\section{Figure captions}

Fig. 1: Modulus and imaginary part of the Fourier transform of the EXAFS oscillations $\mathrm{k}^{2} \chi(\mathrm{k})$ at $\mathrm{T}=15 \mathrm{~K}$ at the $\mathrm{Cu} \mathrm{K}$-edge.

Fig. 2: Modulus and imaginary part of the Fourier transform of the EXAFS oscillations $\mathrm{k}^{2} \chi(\mathrm{k})$ at $\mathrm{T}=15 \mathrm{~K}$ at the $\mathrm{Fe}$ and $\mathrm{Cu} \mathrm{K}$-edges: comparison of experimental data (symbols) and best fits (thick solid lines). The contributions of a given kind of neighbours (modulus only) around a given absorbing atom $(\mathrm{Fe}$ or $\mathrm{Cu})$ are also shown. 


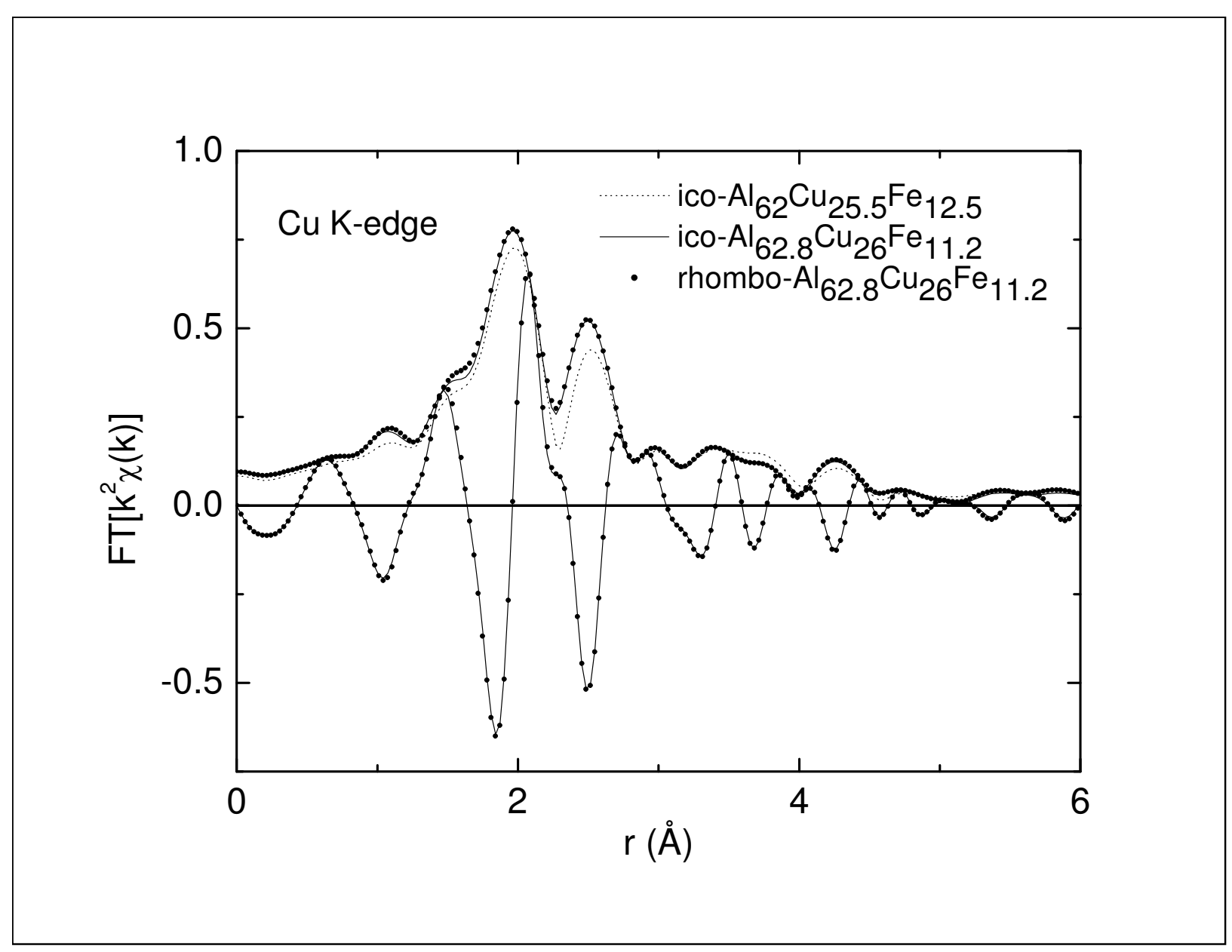

Fig.1 

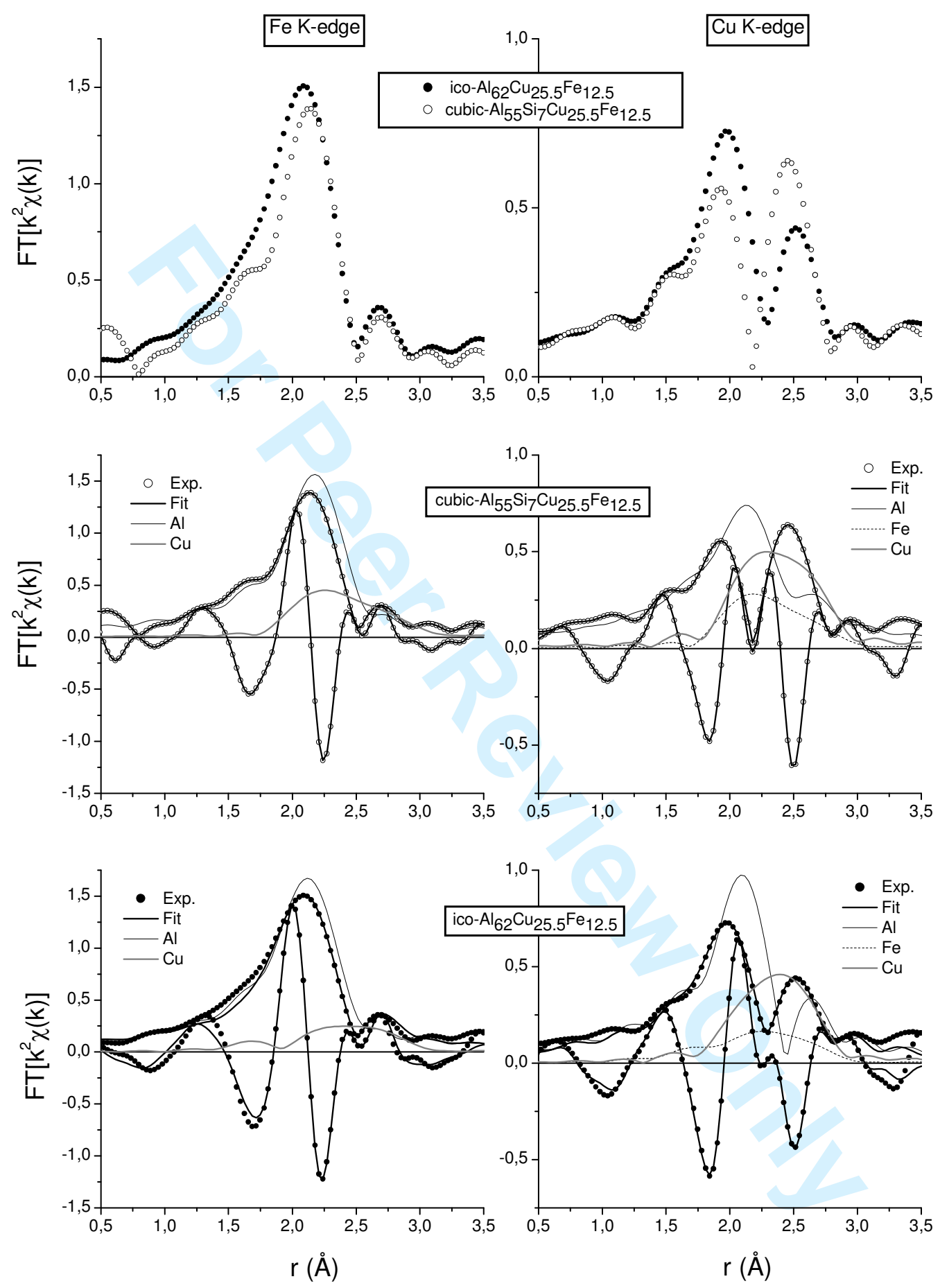

Fig. 2 


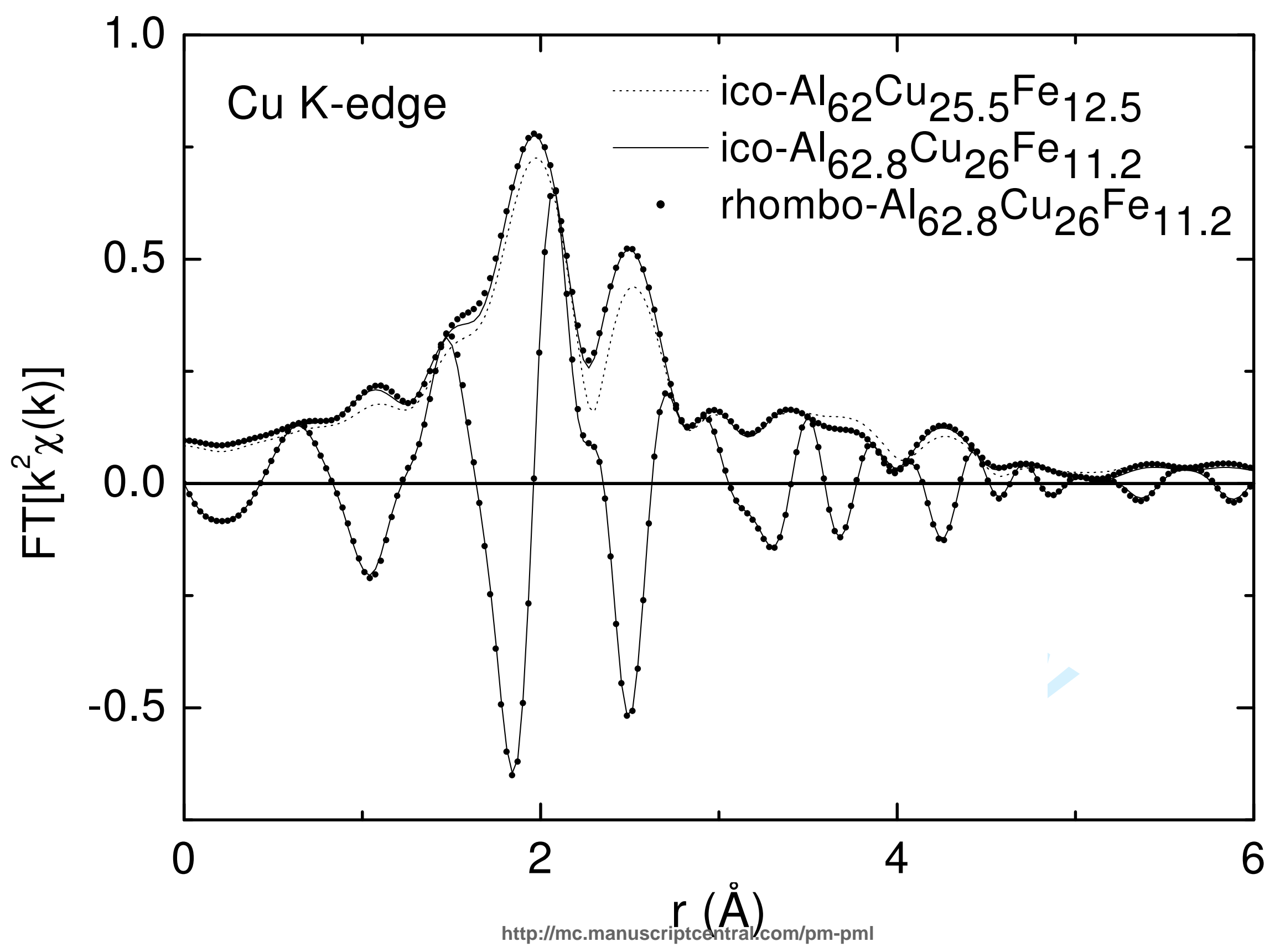



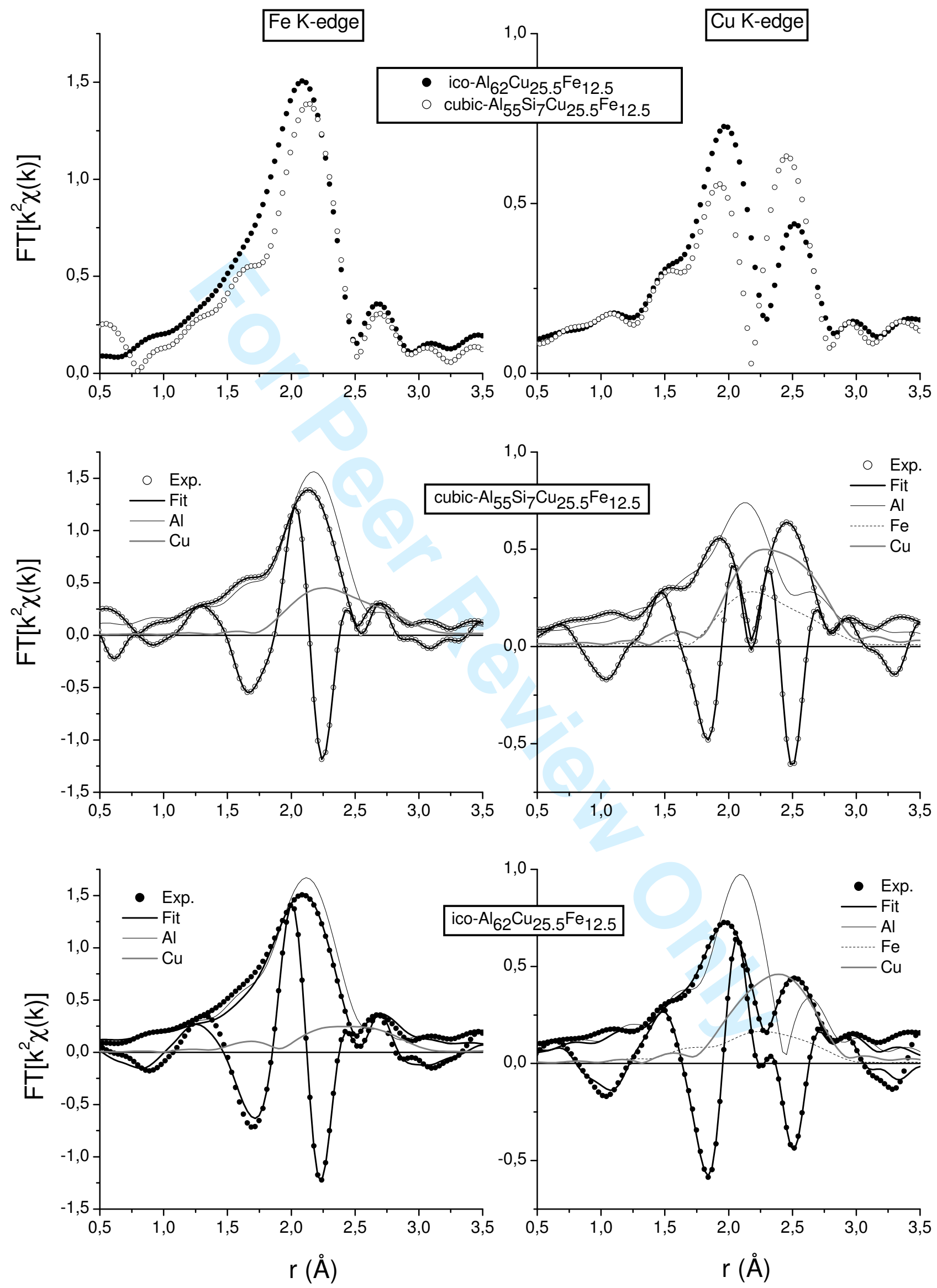